\title{
On the Mechanism of Impaired Insulin Secretion in Chronic Renal Failure
}

\author{
George Z. Fadda, Suha M. Hajjar, Alessandra F. Perna, Xin-Jin Zhou, Loren G. Lipson, and Shaul G. Massry \\ Division of Nephrology and Geriatric Medicine and the Department of Medicine, University of Southern California \\ School of Medicine, Los Angeles, California 90033
}

\begin{abstract}
It has been suggested that a sustained rise in resting levels of cytosolic calcium $\left[\mathrm{Ca}^{2+}\right]_{i}$ of pancreatic islets is responsible for impaired insulin secretion in chronic renal failure (CRF). Evidence for such an event is lacking and the mechanisms through which it may affect insulin secretion are not known. Studies were conducted in normal, CRF, and normocalcemic, parathyroidectomized (PTX) CRF rats to answer these questions.

Resting levels of $\left[\mathrm{Ca}^{2+}\right]_{i}$ of islets from CRF rats were higher $(P<0.01)$ than in control or CRF-PTX rats. [3 $\mathrm{H}] 2$-deoxyglucose uptake and cAMP production by islets were not different in the three groups. Insulin content of, and glucose-induced insulin secretion by islets from CRF rats was lower $(P<0.01)$ than in control and CRF-PTX rats. In contrast, glyceraldehydeinduced insulin release by CRF islets was normal. Basal ATP content, both glucose-stimulated ATP content and ATP/ADP ratio, net lactic acid output, $V_{\max }$ of phosphofructokinase-1, and $\mathrm{Ca}^{2+}$ ATPase of islets from $\mathrm{CRF}$ rats were lower $(P<0.02$ $<0.01$ ) than in normal or CRF-PTX animals.

Data show that: $(a)$ Glucose but not glyceraldehyde-induced insulin secretion is impaired in CRF; (b) the impairment in glucose-induced insulin release in CRF is due to a defect in the metabolism of glucose; $(c)$ this latter defect is due to reduced ATP content induced partly by high $\left[\mathrm{Ca}^{2+} \mathrm{h}_{\mathrm{f}}\right.$ of islets; and $(d)$ the high $\left[\mathrm{Ca}^{2+}\right]_{\text {in }}$ islets of CRF rats is due to augmented PTH-induced calcium entry into cells and decreased calcium extrusion from the islets secondary to reduced activity of the $\mathrm{Ca}^{2+} \mathrm{ATP}$ ase. (J. Clin. Invest. 1991. 87:255-261.) Key words: pancreatic islets • parathyroid hormone $\cdot$ cytosolic calcium • ATP
\end{abstract}

\section{Introduction}

Chronic renal failure (CRF) $)^{1}$ is associated with impaired glucose-induced insulin release from pancreatic islets (1). We have demonstrated that this defect is due to the state of secondary hyperparathyroidism of CRF in that normocalcemic parathyroidectomized (PTX) CRF rats displayed normal glucose-induced insulin release (1). The mechanisms through which excess PTH in CRF impairs insulin release are not delineated. It

Address reprint requests to Dr. S. G. Massry, Division of Nephrology, University of Southern California, School of Medicine, 2025 Zonal Avenue, Los Angeles, CA 90033.

Received for publication 8 January 1990 and in revised form 14 August 1990.

1. Abbreviations used in this paper: CRF, chronic renal failure; IBMX, isobutyl-1-methylxanthine; PFK-1, phosphofructokinase-1; PTX, parathyroidectomized.

J. Clin. Invest.

(c) The American Society for Clinical Investigation, Inc

0021-9738/91/01/0255/07 \$2.00

Volume 87, January 1991, 255-261 has been postulated that PTH augments entry of calcium into islets and leads to calcium accumulation in these structures. This increased calcium burden then interferes with the process of insulin secretion.

Support for such a sequence of events is found in several observations. First, the acute exposure of pancreatic islets to 1-34 PTH is associated with a rise in their cytosolic calcium (2). Second, pancreatic islets obtained from rats treated for $42 \mathrm{~d}$ with 1-84 PTH have significantly and markedly higher resting levels of cytosolic calcium and display impaired insulin release (3). Third, prevention of calcium accumulation in pancreas of CRF rats by treatment with the calcium channel blocker, Verapamil, corrected the impairment in glucose-induced insulin release (4).

Direct evidence demonstrating a rise in resting levels of cytosolic calcium in islets of CRF rats and correction of such derangement by PTX is lacking. In addition, the mechanisms through which a rise in resting levels of cytosolic calcium of the pancreatic islets of CRF rats interfere with their ability to secrete insulin are not delineated. This study was undertaken to examine these issues.

\section{Methods}

Sprague-Dawley rats weighing 275-375 g were studied. They were fed normal rat chow diet (Wayne Research Animal Diets, Chicago, IL) throughout the study and allowed to drink ad lib. The rats were studied after $42 \mathrm{~d}$ of CRF in the presence and absence of the parathyroid glands. Parathyroidectomy was performed by electrocautery, and the success of the procedure was ascertained by a decrease in serum levels of calcium of at least $2 \mathrm{mg} / \mathrm{dl}$. The PTX rats were allowed to freely drink water containing $5 \%$ of calcium gluconate. This procedure is adequate to normalize plasma calcium in the PTX rats. $7 \mathrm{~d}$ after PTX, the animals underwent a right nephrectomy through a flank incision; 4 d later, a partial left nephrectomy was performed. The nephrectomy procedure was also done in rats with intact parathyroid glands. This protocol, therefore, provided two groups of animals with CRF: one with intact parathyroid glands (CRF) and the other without parathyroid glands (CRF-PTX). A group of normal rats served as control for the CRF and CRF-PTX animals.

$2 \mathrm{~d}$ before the experiments, some of the rats were housed in metabolic cages for the collection of 24-h urine output. The animals were killed by decapitation on day 43 after the partial left nephrectomy. The pancreas was removed, dissected free of adipose tissue and lymph nodes. Islets of Langerhans were isolated by the collagenase digestion method of Lacy and Kostianovsky (5) and picked free of exocrine tissue under a dissecting microscope. Studies were conducted on islets obtained from normal, CRF, and CRF-PTX rats.

Studies of insulin secretion by islets. Insulin secretion from islets of the various groups of animals was evaluated under dynamic conditions according to methods previously reported $(6,7)$. These dynamic studies were conducted in a four-channel perifusion apparatus. 25 sizematched islets were placed in each of the four conical chambers of $0.07-\mathrm{ml}$ capacity and were perifused at a rate of $0.8 \mathrm{ml} / \mathrm{min}$ with the incubation media (modified KRB [pH 7.4]) containing $10 \mathrm{mM}$ Hepes and $0.5 \mathrm{mg} / \mathrm{dl} \mathrm{BSA}$, having $2.8 \mathrm{mM}$ D-glucose at a temperature of $37^{\circ} \mathrm{C}$ and a gas mixture of $95 \% \mathrm{O}_{2}$ and $5 \% \mathrm{CO}_{2}$ being continuously bubbled 
into the perifusate. After leaving the chambers, the perifusate was filtered through 8.0- $\mu \mathrm{m}$ pore size filter (Sartorius Filters, Inc., Burlingame, CA) and was collected. After 30 min of preincubation, the collection of the effluent was started and continued at 1-min intervals for 41 $\mathrm{min}$. The first six collections $(6 \mathrm{~min})$ represented the basal level of insulin release during perifusion at $2.8 \mathrm{mM}$ D-glucose. Thereafter, the D-glucose concentration in the perifusate was increased to $16.7 \mathrm{mM}$ and an additional 35 samples were collected. In another group of studies the insulin secretagogue was $10 \mathrm{mM}$ D-glyceraldehyde. Insulin concentrations were determined in the various samples of the effluent. In these dynamic studies of insulin release, the changes from baseline with time were examined by calculating the area under the curve for each study, allowing us to estimate insulin release during the initial phase and the total insulin release.

Cyclic AMP of islets. Static studies were conducted for the measurement of cAMP in the islets. Briefly, 10 islets were incubated for $30 \mathrm{~min}$ at $37^{\circ} \mathrm{C}$ in $1.0 \mathrm{ml}$ of incubation media containing $(a) 2.8 \mathrm{mM}$ D-glucose; (b) $16.7 \mathrm{mM}$ D-glucose; (c) $10 \mathrm{mM}$ D-glyceraldehyde and $2.8 \mathrm{mM}$ D-glucose; or $(d) 16.7 \mathrm{mM}$ D-glucose and $100 \mu \mathrm{M}$ isobutyl-1-methylxanthine (IBMX). At the end of the incubation the cAMP was extracted by the addition of $120 \mu 110 \%$ perchloric acid, and the solution was then neutralized with $90 \mu$ l of potassium carbonate and centrifuged at $3,000 \mathrm{~g}$ for $10 \mathrm{~min}$. The supernates were saved. The pellet was washed and centrifuged two more times and the supernate was saved after each centrifugation. The pooled aqueous extract was dried at $60^{\circ} \mathrm{C}$. Before cAMP assay, the extract was reconstituted with $1 \mathrm{ml}$ of assay buffer and cAMP was measured using the CAMP $\left({ }^{125} \mathrm{I}\right)$ assay kit (Amersham Corp., Arlington Heights, IL).

Adenine nucleotide content of islets. Both ATP and ADP content of islets were measured simultaneously by the methods of Ashcroft et al. (8) and of Lundin et al. (9). 10 islets were placed in $400 \mu \mathrm{KRB}$ incubation medium containing either 2.8 or $16.7 \mathrm{mM}$ D-glucose and incubated for $30 \mathrm{~min}$ at $37^{\circ} \mathrm{C}$. At the end of the incubation, $200 \mu \mathrm{l}$ of the medium containing the islets was mixed with TCA with a final concentration of $2.5 \%$, and the tube containing the mixture was immersed in liquid nitrogen and stored at $-70^{\circ} \mathrm{C}$. On the day of the assay, the mixture was thawed and neutralized with $2 \mathrm{~N} \mathrm{KHCO}_{3}$. 50- $\mu$ l samples of the mixture were assayed for ATP before and after conversion of ADP to ATP by adding phosphoenol pyruvate $(0.2 \mathrm{M})$ and pyruvate kinase $(10 \mathrm{mg} / \mathrm{dl})$. The difference between the two values represents the ADP content. ATP was measured by the firefly luminescence assay with the LAD 535 Luminometer (Turner Designs, Sunnyvale, CA). ATP standards were prepared with KRB medium and contained the same amount of TCA and $\mathrm{KHCO}_{3}$ as the islet extracts.

$V_{\max }$ and $K_{m}$ for fructose of phosphofructokinase 1 (PFK-1). The $V_{\max }$ and apparent $K_{\mathrm{m}}$ for fructose-6-phosphate of islet PFK-1 (E.C.2.7.1.11) were determined by the methods of Beutler et al. (10) and of Hyslop et al. (11). Islets were pelleted in a microfuge (Beckman Instruments, Inc., Palo Alto, CA) for $5 \mathrm{~s}$ and resuspended in a solution containing $0.1 \mathrm{M}$ Tris, $5 \mathrm{mM} \mathrm{MgCl}_{2}$ (pH 8.0), $2 \mathrm{mM}$ EGTA, and 100 $\mu \mathrm{M} \beta$-mercaptoethanol, and then sonicated at low power (Braunsonic 1510; B-Braun Instruments, Melsungen AG, FRG) for $20 \mathrm{~s}$ at $4^{\circ} \mathrm{C}$. Appropriate amounts of the following reagents were added to the islet preparation to attain a final volume of $900 \mu \mathrm{l}$ made of: $100 \mu \mathrm{l}$ of $1 \mathrm{M}$ Tris HCL; 5 mM EDTA (pH 8.0); $200 \mu \mathrm{l}$ of $0.1 \mathrm{mM} \mathrm{MgCl}_{2} ; 100 \mu \mathrm{l}$ of $0.02 \mathrm{M}$ fructose-6-phosphate (or progressively decreasing concentrations for the assessment of $K_{\mathrm{m}}$ ); $100 \mu \mathrm{l}$ of $2 \mathrm{mM}$ NADH; $250 \mu \mathrm{l}$ distilled water; $50 \mu \mathrm{l}$ islets; and $100 \mu \mathrm{l}$ of auxiliary enzyme solution. The latter solution was prepared by adding $100 \mathrm{U}$ of aldolase, $100 \mathrm{U}$ of triose phosphate isomerase, $100 \mathrm{U}$ of $\alpha$-glycerophosphate dehydrogenase to a saturated $\left(\mathrm{NH}_{4}\right)_{2} \mathrm{SO}_{4}$ solution, bringing the total volume to $2 \mathrm{ml}$. This $\left(\mathrm{NH}_{4}\right)_{2} \mathrm{SO}_{4}$ solution was then diluted $1: 15$ in $\beta$-mercaptoethanolEDTA stabilizing solution. A blank was prepared exactly as described above except for the deletion of fructose-6-phosphate. The mixture was then incubated at $37^{\circ} \mathrm{C}$ for $10 \mathrm{~min}$. Thereafter, $100 \mu \mathrm{l}$ of $0.02 \mathrm{M} \mathrm{ATP}$ was added making the final volume of the assay $1 \mathrm{ml}$. The activity of PFK-1 was assayed by the measurement of NADH oxidation at 340 $\mathrm{nm}$ wavelength using a spectrophotometer (model LAMBDA 2; Per-
kin-Elmer Corp., Instrument Div., Norwalk, CT). The $V_{\max }$ of PFK-1 was expressed as nanomoles per minute per milligrams of protein. The protein concentration was determined by the method of Bradford (12). The Michaelis-Menten constant for fructose-6-phosphate was estimated in its linear form as the Lineweaver-Burk double reciprocal plot, generated from at least five concentrations of the substrate. A plot of the reciprocal of the initial velocity versus the reciprocal of the initial substrate concentration yields a line whose slope is $K_{\mathrm{m}} / V_{\max }$, whose $y$ intercept is $1 / V_{\max }$, and whose $x$ intercept is $-1 / K_{\mathrm{m}}$.

Measurement of glucose-6-phosphate and glycerol-phosphate. The measurements of picomole quantities of these compounds in the pancreatic islets could not be done reliably because of the small quantities of tissue available for the assay. To find whether CRF affects the contents of these compounds in cells, we measured them in both the myocardium and skeletal muscle of control, CRF, and CRF-PTX rats. The measurements were made with the Bessman automatic phosphate analyzer which is, in principle, a high pressure liquid chromatography on an anion-exchange resin column for separation of phosphorylated intermediates (13). The details of obtaining the myocardial or skeletal muscle, their extraction, and the analysis of these compounds were previously reported in detail from our laboratory (14).

Lactate assay. Lactic acid output by islets was determined after their incubation with 2.8 and $16.7 \mathrm{mM}$ D-glucose using the method of Sener and Malaisse (15). The assay estimates the level of NADH liberated at the end of the reaction generated by the addition of $0.5 \mathrm{mM}$ $\mathrm{NAD}, 50 \mu \mathrm{g}$ lactic dehydrogenase, $2 \mathrm{mM}$ glutamate, $50 \mu \mathrm{g}$ glutamicpyruvic transaminase, and $50 \mathrm{mM}$ 2-amino-2-methyl-propanol to a cuvette with a final volume of $2 \mathrm{ml}$ containing either islets or a standard. The measurement of NADH was done with a Perkin-Elmer fluorometer at excitation wavelength of $340 \mathrm{~nm}$ and emission wavelength of $450 \mathrm{~nm}$. The difference between lactic acid output by islets incubated with 2.8 and $16.7 \mathrm{mM}$ D-glucose was calculated, and this net lactic acid output was considered to be produced by metabolism of glucose by the islets.

Cytosolic calcium of islets. Cytosolic calcium of islets was measured with Fura 2-AM (Sigma Chemical Co., St. Louis, MO) using a modification of the method described by Sussman, Leitner, and Draznin (16). The pancreatic islets were isolated using the collagenase digestion method described above and picked under a dissecting microscope. 500 islets were then dissociated into single cells and small clusters by shaking in a calcium and magnesium-free medium supplemented with EGTA $(0.2 \mathrm{mg} / \mathrm{ml})$ and trypsin $(0.5 \mathrm{mg} / \mathrm{ml})$ for $10 \mathrm{~min}$ at room temperature. The suspension was then centrifuged at $500 \mathrm{~g}$ for $3 \mathrm{~min}$ and the pellet resuspended in modified $\mathrm{KRB}$ containing $135 \mathrm{mM} \mathrm{NaCl}, 5 \mathrm{mM}$ $\mathrm{KCl}, 1.5 \mathrm{mM} \mathrm{CaCl}_{2}, 1 \mathrm{mM} \mathrm{MgCl}$, $2 \mathrm{mM} \mathrm{NaH}_{2} \mathrm{PO}_{4}, 6 \mathrm{mM}$ Hepes, 2.8 $\mathrm{mM}$ D-glucose, $1 \mathrm{~g}$ /liter BSA (fraction $\mathrm{V}$ ) (pH 7.4). The suspension was aspirated 10 times through a 14-gauge needle at room temperature and then incubated at $37^{\circ} \mathrm{C}$ for 3 min with gentle shaking. The islets were then disrupted into individual cells with eight aspirations through a 20 -gauge needle. The cells were then centrifuged at $500 \mathrm{~g}$ for $3 \mathrm{~min}$ and washed in the above solution. Loading of the cells with Fura 2-AM was done by incubating them with $2 \mu \mathrm{M}$ of Fura 2-AM for $30 \mathrm{~min}$. This was followed by washing and centrifugation at $500 \mathrm{~g}$ for $3 \mathrm{~min}$ at room temperature. Measurement of fluorescence was done with PerkinElmer fluorescence spectrophotometer model LS 5B at excitation wavelength of 340 and $380 \mathrm{~nm}$, and emission wavelength of $510 \mathrm{~nm}$. Maximal fluorescence and minimal fluorescence were estimated as previously reported $(17,18)$. The cells were lysed with digitonin $(40$ $\mu \mathrm{g} / \mathrm{ml}$ ) to obtain maximal fluorescence. Next, $10 \mathrm{mM}$ EGTA and sufficient $\mathrm{NaOH}$ to elevate the $\mathrm{pH}$ to 8.5 were added to obtain minimal fluorescence. Cells were washed before each experiment, and the above mentioned calibration for the Fura 2 signal was performed after each experiment. To eliminate the effects of autofluorescence due to the cuvette, medium, and islets, fluorescence was measured with empty cuvette, after addition of medium and after addition of cells without Fura 2 . The unloaded pancreatic islets produced very minimal and almost undetectable fluorescence. Correction for the autofluorescence of the cuvette and medium was made by setting the fluorometer on 
autozero before each measurement. Calculation of cytosolic calcium was made using Grynkiewicz's equation (17). The dissociation constant for $\mathrm{Ca}^{2+}$-Fura 2 was assumed to be $225 \mathrm{nM}$ (17).

$\left[{ }^{3} \mathrm{H}\right] 2$-deoxyglucose uptake of islets. $\left[{ }^{3} \mathrm{H}\right] 2$-deoxyglucose (Amersham Corp., sp act $17 \mathrm{Ci} / \mathrm{mmol}$ glucose) uptake was measured using 400 islets according to a modification of the method described by Draznin et al. (19). The islets were disrupted into single cells as described above under the methodology for the measurement of cytosolic calcium. $0.2 \mu \mathrm{Ci}$ of $\left[{ }^{3} \mathrm{H}\right] 2$-deoxyglucose were added to $1 \mathrm{ml}$ of islet suspension while on ice. Samples of $100 \mu \mathrm{l}$ were taken at 0 time and transferred to a microcentrifuge tube containing $100 \mu \mathrm{l}$ of silicone oil and centrifuged in a Beckman 152 microfuge. The pellet was counted for radioactivity in a Beckman liquid scintillation counter. These counts were considered to represent the nonspecific binding of $\left[{ }^{3} \mathrm{H}\right] 2$-deoxyglucose to the islets. The remaining islet suspension was incubated in a shaker bath at $37^{\circ} \mathrm{C}$ for $5 \mathrm{~min} ; 100-\mu \mathrm{l}$ samples were transferred to a microcentrifuge tube containing $100 \mu$ l of silicone oil and centrifuged. The pellets were counted as described above. The difference between the counts at $5 \mathrm{~min}$ and at time 0 were considered to represent glucose uptake by the islets.

Measurements of calcium-dependent ATPase ( $\left.\mathrm{Ca}^{+2} \mathrm{ATPase}\right)$. Pancreatic islet membranes were prepared according to a modification of the method described by Levin et al. (20). Groups of 60 islets were suspended in $600 \mu \mathrm{l}$ of $300 \mathrm{mM}$ sucrose and $10 \mathrm{mM}$ Tris- $\mathrm{HCl}$ (pH 7.4) at $4^{\circ} \mathrm{C}$ and then sonicated with Braunsonic 1510 sonicator while on ice for $10 \mathrm{~s}$. The suspension was centrifuged at 1,500 in refrigerated Sorvall centrifuge model RC-2B (DuPont Co., Newton, CT) with an SM-24 rotor for $10 \mathrm{~min}$ and the pellet was resuspended in the same solution and sonicated again for $10 \mathrm{~s}$ at $4^{\circ} \mathrm{C}$. The suspension was then centrifuged at $1,500 \mathrm{~g}$ for $10 \mathrm{~min}$ and the pellet was resuspended in $600 \mu \mathrm{l}$ of 3 $\mathrm{mM}$ Tris- $\mathrm{HCl}\left(\mathrm{pH} \mathrm{7.4)}\right.$ at $4^{\circ} \mathrm{C}$ and homogenized with a homogenizer (Thomas Scientific, Swedesboro, NJ) by four passes of the plunger. The homogenate was immediately frozen and stored at $-70^{\circ} \mathrm{C}$ for $2-3 \mathrm{~d}$ before the assay of $\mathrm{Ca}^{+2}$ ATPase activity.

The membrane $\mathrm{Ca}^{2+}$ ATPase activity was determined by continuous monitoring of ATP consumption using the firefly luciferase bioluminescence assay for determination of ATP (21) with LAD 535 luminometer as described above. A sample of $100 \mu \mathrm{l}$ of membrane homogenate (equivalent to 10 islets) was added to $850 \mu \mathrm{l}$ of incubation solution containing various concentrations of calcium chloride $(0.8,1.0,1.4$, 1.8 , or $2.0 \mathrm{mM}$, that are equivalent to $0.01,0.015,0.024,0.10$, or 5.4 $\mu \mathrm{M}$ free $\mathrm{Ca}^{++}$, respectively), $2 \mathrm{mM}$ EGTA, $20 \mathrm{mM} \mathrm{NaN}_{3}, 0.1 \mathrm{mM}$ ouabain, $10 \mathrm{mM}$ Tris-Pipes (piperazine- $N, N^{\prime}$-bis[2-ethane sulfonic acid]) (pH 7.5), and preincubated for $10 \mathrm{~min}$ at $37^{\circ} \mathrm{C}$. At the end of this preincubation, $50 \mu \mathrm{l}$ of $20 \mathrm{mM}$ Tris ATP stock solution was added bringing the final volume of mixture to $1 \mathrm{ml}$ and giving a concentration of ATP of $1 \mathrm{mM}$. This mixture was incubated for $1 \mathrm{~h}$.

The ATP level was determined before and at the end of $1 \mathrm{~h}$ incubation and ATP consumption was calculated as the difference between these two values. Nonenzymatic hydrolysis of ATP was determined during similar incubation of $100 \mu \mathrm{l}$ of $3 \mathrm{mM}$ Tris- $\mathrm{HCl}(\mathrm{pH}$ 7.4) with $850 \mu \mathrm{l}$ of incubation solution and $50 \mu \mathrm{l}$ of $20 \mathrm{mM}$ ATP. This nonenzymatic hydrolysis of ATP averaged 5\%. The actual enzymatic ATP hydrolysis during each experiment was calculated by correction of the total ATP consumption for spontaneous ATP hydrolysis. The $\mathrm{Ca}^{2+}$ ATPase assay was done in the presence of endogenous tissue magnesium that was measured and found to be 8-9 $\mu \mathrm{M}$. The Mg-ATPase activity was measured simultaneously during each study in the absence of free calcium in the incubation media. The $\mathrm{Ca}^{2+}$ ATPase activity was calculated as the difference between the ATP consumption in the presence and absence of calcium. The concentration of protein was determined by the method of Bradford (12).

For the determination of free calcium concentrations, the apparent Ca-EGTA association constant of $10^{7.832} \mathrm{M}^{-1}$ for $\mathrm{pH} 7.5$ was used (22). The high affinity $\mathrm{Ca}^{+2}$ ATPase was studied at a concentration of free calcium of $\leq 5.4 \mu \mathrm{M}$; under these conditions ATP has a negligible effect on free calcium in a Ca-EGTA buffer system because the apparent Ca-ATP association constant of $10^{3.390} \mathrm{M}^{-1}$ at $\mathrm{pH} 7.5$ is much less than that of Ca-EGTA. The $K_{\mathrm{m}}$ for Ca was calculated using the Lineweaver-Burk line generated from five different concentrations of substrate.

The choice of $1 \mathrm{~h}$ incubation for the measurement of $\mathrm{Ca}^{2+}$ ATPase was based on observations in preliminary study in which the activity of the enzyme was measured at different time intervals. It was found that the relationship between the activity of the $\mathrm{Ca}^{2+}$ ATPase and time of incubation was linear during the first $60 \mathrm{~min}$. Similarly the dose of 1 mM ATP was based on preliminary studies evaluating the effect of different concentrations of ATP on $\mathrm{Ca}^{2+}$ ATPase. The total ATPase activity $\left(\mathrm{Ca}^{2+}\right.$ and $\mathrm{Mg}^{2+}$ ATPase $)$ as well as that of $\mathrm{Mg}^{2+}$ ATPase and hence the $\mathrm{Ca}^{2+}$ ATPase activity began to plateau at $1 \mathrm{mM}$ ATP.

The measurements of calcium and magnesium concentrations in plasma were made by Perkin-Elmer atomic absorption spectrophotometer, model 503, and those of plasma and urine creatinine and plasma phosphorus by autoanalyzer (Technicon Instruments Corp., Tarrytown, NY). Insulin was determined by charcoal-coated radioimmunoassay using rat insulin as standard (23). PTH levels in serum were determined by INS-PTH immunoassay kit (Nichols Institute Diagnostics, San Juan Capistrano, CA). This assay recognizes the amino-terminal fragment of PTH. The assay showed highly reproducible $\mathrm{IC}_{\mathbf{5 0}}$ for inhibition of ${ }^{125} \mathrm{I}-\mathrm{PTH}$ binding of $21.4 \pm 0.8 \mathrm{pg}$, and $<10 \%$ differences within an assay. The lower limit of detectability of PTH with this assay is $10 \mathrm{pg} / \mathrm{ml}$.

Statistical analysis was done with the Clinfo computer system. The data are presented as mean $\pm S E$. Changes from baseline in parameters with multiple measurements with time (dynamic insulin secretion with D-glucose) were evaluated by calculating area under the curve for each experiment using the trapezoidal rule. The statistical significance between the various parameters was evaluated by unpaired $t$ test.

\section{Results}

The body weight and biochemical data of the three groups of rats are given in Table I. There were no significant differences in body weight and in the serum levels of calcium, phosphorus, and magnesium. The $5 / 6$ nephrectomy resulted in a significant rise in the serum levels of creatinine with the values being three times higher than in control rats $(P<0.01)$. However, there was no significant difference in the levels of serum creatinine between the CRF and CRF-PTX rats. Table II provides the data on creatinine clearance and serum levels of PTH in control, CRF, and CRF-PTX rats. Creatinine clearance was significantly $(P<0.01)$ lower in CRF and CRF-PTX rats than in control animals, and there were no significant differences in this parameter between CRF and CRF-PTX rats. The serum levels of PTH were significantly $(P<0.01)$ elevated in CRF rats with the values being twice that of the normal animals. In the

Table I. Biochemical Data in Control, CRF, and CRF-PTX Rats

\begin{tabular}{cccccc}
\hline & & \multicolumn{5}{c}{ Plasma } \\
\cline { 3 - 6 } & Body wt & $\mathrm{Cr}$ & $\mathrm{Ca}$ & $\mathrm{P}$ & $\mathrm{Mg}$ \\
\hline \multicolumn{3}{c}{$g$} & & \multicolumn{2}{c}{$m g / d l$} \\
$\begin{array}{c}\text { Control } \\
n=42\end{array}$ & $338 \pm 11.7$ & $0.33 \pm 0.02$ & $10.1 \pm 0.21$ & $6.5 \pm 0.34$ & $2.57 \pm 0.04$ \\
$\begin{array}{c}\text { CRF } \\
n=37\end{array}$ & $330 \pm 9.1$ & $1.00 \pm 0.06^{*}$ & $10.3 \pm 0.18$ & $6.4 \pm 0.18$ & $2.65 \pm 0.08$ \\
$\begin{array}{c}\text { CRF-PTX } \\
n=29\end{array}$ & $321 \pm 10.1$ & $1.12 \pm 0.11^{*}$ & $9.9 \pm 0.36$ & $5.7 \pm 0.19$ & $2.47 \pm 0.06$
\end{tabular}

Data are presented as mean $\pm \mathrm{SE}$.

$* P<0.01$ vs. control. 
Table II. Data on Creatinine Clearance and Serum Levels of PTH in Control, CRF, and CRF-PTX Rats

\begin{tabular}{lcccc}
\hline & Serum Cr & Urine Cr & \multicolumn{1}{c}{ Ccr } & Serum PTH \\
\hline & $m g / d l$ & $m g / 24 h$ & $m l / m i n$ & $p g / m l$ \\
Control & $0.32 \pm 0.02$ & $11.7 \pm 1.22$ & $2.50 \pm 0.18$ & $41 \pm 2.3$ \\
CRF & $1.19 \pm 0.12^{*}$ & $13.0 \pm 1.30$ & $0.83 \pm 0.10^{*}$ & $76 \pm 5.7^{* \neq}$ \\
CRF-PTX & $1.12 \pm 0.13^{*}$ & $10.8 \pm 1.8$ & $0.65 \pm 0.07^{*}$ & $23 \pm 0.6^{*}$
\end{tabular}

$\mathrm{Cr}$, creatinine; $\mathrm{Ccr}$, creatinine clearance.

The number of rats studied for measurements of creatinine clearance was 10 in each group. The number of studies for measurement of PTH was 11 control, 10 CRF, and 6 CRF-PTX.

Data are presented as mean \pm 1 SE.

${ }^{*} P<0.01$ vs. control; ${ }^{\ddagger} P<0.01$ vs. CRF-PTX and control.

CRF-PTX rats, the serum levels of PTH were significantly ( $P$ $<0.01)$ lower than those in both normal or CRF rats.

Fig. 1 depicts the data of the dynamic studies on D-glucoseinduced insulin release from pancreatic islets obtained from control, CRF, and CRF-PTX rats. Both the initial and total insulin release in CRF rats $(80 \pm 17 \mathrm{pg} /$ islet per $6 \mathrm{~min}$ and $985 \pm 66 \mathrm{pg} /$ islet per $31 \mathrm{~min})$ were significantly $(P<0.01)$ smaller than in control rats $(363 \pm 58 \mathrm{pg} /$ islet per $6 \mathrm{~min}$ and $3,477 \pm 250 \mathrm{pg} /$ islet per $31 \mathrm{~min}$ ) or in CRF-PTX animals $(243 \pm 13 \mathrm{pg} /$ islet per $6 \mathrm{~min}$ and $2,918 \pm 322 \mathrm{pg} /$ islet per $31 \mathrm{~min})$. The values of the last two groups of animals were not different.

$\left[{ }^{3} \mathrm{H}\right] 2$-deoxyglucose uptake by islets was not affected by CRF and the values of the uptake in CRF rats $(3.7 \pm 0.5 \mathrm{fmol} / 5$ min) were not different from those in CRF-PTX animals $(4.3 \pm 0.6 \mathrm{fmol} / 5 \mathrm{~min})$ or control rats $(4.1 \pm 0.1 \mathrm{fmol} / 5 \mathrm{~min})$. Insulin content in CRF rats $(31 \pm 2.7 \mathrm{ng} /$ islet $)$ was significantly $(P<0.01)$ lower than in control rats $(49 \pm 5.3 \mathrm{ng} / \mathrm{islet})$ or in

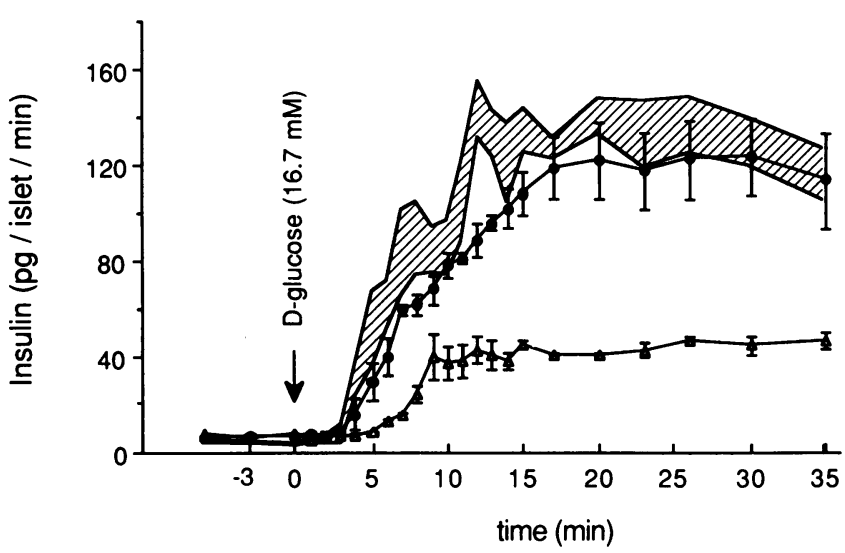

Figure 1. Dynamic studies of D-glucose-induced insulin release from perifused pancreatic islets of five control, five CRF, and five CRFPTX rats. Insulin secretion was first measured during dynamic perifusion with KRB containing $2.8 \mathrm{mM}$ D-glucose. At 0 time, the glucose concentration of the perifusate was increased to $16.7 \mathrm{mM}$. The shaded area represents mean \pm 1 SE of insulin release in islets from control rats. The closed circles represent insulin release from CRF-PTX rats and the open triangles that from CRF rats. Each data point represents the mean value and the brackets depict SE. The areas under the curve of the initial phase and of total insulin release in CRF rats are significantly smaller than those in control and CRFPTX rats.
CRF-PTX animals ( $43 \pm 1.5 \mathrm{ng} /$ islet). The latter value was not different from that of control animals.

Table III provides the simultaneous values of ATP and ADP content, and of ATP/ADP ratio in islets from control, CRF, and CRF-PTX rats. Both the basal and the glucose-stimulated ATP content extracted were significantly $(P<0.01)$ lower in CRF than in control or CRF-PTX rats. The ADP content in CRF and CRF-PTX rats was lower than in control rats $(P<0.05)$. The ATP/ADP ratio in CRF did not increase after the exposure to $16.7 \mathrm{mM}$ D-glucose while a significant $(P$ $<0.01$ ) increment was observed in this ratio both in control and CRF-PTX rats.

The $V_{\max }$ of PFK-1 in CRF rats $(5.9 \pm 0.29 \mathrm{nmol} / \mathrm{min}$ per mg protein) was significantly $(P<0.01)$ lower than that in normal rats $(7.5 \pm 0.7 \mathrm{nmol} / \mathrm{min}$ per $\mathrm{mg}$ protein) or in CRFPTX $(7.0 \pm 0.37 \mathrm{nmol} / \mathrm{min}$ per $\mathrm{mg}$ protein) animals. There were no significant differences between the values of $V_{\max }$ in the control and CRF-PTX rats. There was also no significant difference in the $K_{\mathrm{m}}$ for fructose-6-phosphate of PFK-1 among the three groups of animals (control, $0.333 \pm 0.018 \mathrm{mM}$; CRF, $0.285 \pm 0.032 \mathrm{mM}$; and CRF-PTX, $0.331 \pm 0.046 \mathrm{mM}$ ).

The content of glucose-6-phosphate and glycerol-3 phosphate in both the heart and skeletal muscle was significantly $(P$ $<0.01$ ) lower in CRF rats than in control and CRF-PTX animals (Table IV). The net lactic acid output by pancreatic islets from CRF rats (142 $\pm 30.7 \mathrm{pmol} /$ islet per $90 \mathrm{~min})$ was significantly $(P<0.02)$ lower than by islets from control $(313 \pm 48.5$ $\mathrm{pmol} /$ islet per $90 \mathrm{~min})$ or CRF-PTX rats $(325 \pm 58.1 \mathrm{pmol} / \mathrm{islet}$ per $90 \mathrm{~min}$ ) (Table IV).

The data of the dynamic studies on glyceraldehyde-induced insulin secretion is shown in Fig. 2. There was no significant difference in the insulin secretion induced by this secretagogue among the three groups of rats. cAMP content of islets from normal or CRF rats after stimulation with glucose $(8.5 \pm 1.3 \mathrm{vs}$. $8.1 \pm 0.9 \mathrm{fmol} /$ islet $),$ IBMX (14.1 $\pm 0.5 \mathrm{vs.} 14.1 \pm 2.5 \mathrm{fmol} /$ islet $)$, or glyceraldehyde $(9.3 \pm 1.4 \mathrm{vs} .8 .3 \pm 1.0 \mathrm{fmol} /$ islet $)$ were not different.

The resting levels of cytosolic calcium in pancreatic islets from CRF rats $(252 \pm 7.4 \mathrm{nM})$ were significantly $(P<0.01)$ higher than those observed in islets from control rats $(137 \pm 4.5$ $\mathrm{nM})$ or CRF-PTX animals $(158 \pm 9.8 \mathrm{nM})$. The values of control and CRF-PTX were not different.

Fig. 3 shows the Lineweaver-Burk double reciprocal plots of a $K_{\mathrm{m}}$ study for calcium of $\mathrm{Ca}^{2+}$ ATPase of pancreatic islets in representative studies from control, CRF, and CRF-PTX rats. There were no significant differences in the values of the $K_{\mathrm{m}}$ (control: $0.025 \pm 0.010 \mu \mathrm{M}$; CRF: $0.030 \pm 0.009 \mu \mathrm{M}$; and CRFPTX: $0.029 \pm 0.007 \mu \mathrm{M})$. In contrast the $V_{\max }$ of $\mathrm{Ca}^{2+}$ ATPase in CRF rats $(8.9 \pm 1.26 \mu \mathrm{mol} / \mathrm{mg}$ protein per $\mathrm{h})$ was significantly lower $(P<0.01)$ than in control rats $(15.2 \pm 0.94 \mu \mathrm{mol} / \mathrm{mg}$ protein/h) or in CRF-PTX animals (12.5 $\pm 1.13 \mu \mathrm{mol} / \mathrm{mg}$ protein/ h). There were no significant differences between the $V_{\max }$ values in control and CRF-PTX rats. These differences in $V_{\max }$ could not have been due to differences in protein content of islets membranes in the three groups of animals. The protein content of the islet membranes was $17 \pm 0.9 \mu \mathrm{g}$ per 10 islets in control animals, $20 \pm 1.5 \mu \mathrm{g}$ per 10 islets in CRF rats, and $20 \pm 1.2 \mu \mathrm{g}$ per 10 islets in CRF-PTX animals.

\section{Discussion}

Previous studies from our laboratory have clearly demonstrated that insulin secretion by pancreatic islets is impaired in 
Table III. ATP and ADP content, ATP/ADP Ratio of Pancreatic Islets from Control, CRF, and CRF-PTX Rats

\begin{tabular}{|c|c|c|c|c|c|c|}
\hline & \multicolumn{2}{|c|}{$\begin{array}{c}\text { ATP } \\
\text { pmol/islet }\end{array}$} & \multicolumn{2}{|c|}{$\begin{array}{c}\text { ADP } \\
\text { pmol/islet }\end{array}$} & \multicolumn{2}{|c|}{$\begin{array}{l}\text { ATP/ADP } \\
\text { ratio }\end{array}$} \\
\hline & \multicolumn{2}{|c|}{ mM D-glucose } & \multicolumn{2}{|c|}{ mM D-glucose } & \multicolumn{2}{|c|}{ mM D-glucose } \\
\hline $\begin{array}{l}\text { Control } \\
\qquad n=10\end{array}$ & $14.1 \pm 1.1$ & $27.1 \pm 1.30$ & $3.2 \pm 0.20$ & $3.8 \pm 0.23$ & $4.6 \pm 0.44$ & $7.1 \pm 0.36$ \\
\hline $\begin{array}{l}\text { CRF } \\
\quad n=7\end{array}$ & $8.7 \pm 0.59^{*}$ & $11.6 \pm 0.75^{*}$ & $2.1 \pm 0.28^{\ddagger}$ & $2.7 \pm 0.23^{\ddagger}$ & $4.0 \pm 0.30$ & $4.5 \pm 0.44^{*}$ \\
\hline $\begin{array}{c}\text { CRF-PTX } \\
n=6\end{array}$ & $14.2 \pm 1.1$ & $24.5 \pm 1.7$ & $2.3 \pm 0.10^{\ddagger}$ & $2.4 \pm 0.10^{\ddagger}$ & $5.9 \pm 0.45$ & $10.1 \pm 0.45^{\ddagger}$ \\
\hline
\end{tabular}

Data are presented as mean \pm SE. ${ }^{*} P<0.01$ vs. control and CRF-PTX; ${ }^{\ddagger} P<0.01$ vs. control.

CRF, and this defect is mediated by the state of secondary hyperparathyroidism of CRF (1). Support for this conclusion was found in other studies demonstrating that insulin secretion in CRF-PTX rats and dogs is normal $(1,24)$ and that chronic administration of PTH to rats with normal renal function also impairs insulin secretion $(1,3)$. The state of excess PTH was associated with increased total calcium of pancreas and it has been postulated that this increase in pancreatic calcium may reflect a rise in resting cytosolic calcium of all pancreatic cells including those of the pancreatic islets $(1,4)$ which in turn may impair insulin release.

The results of this study provide direct evidence for the notion that the resting levels of cytosolic calcium of the islets are indeed markedly elevated in CRF rats, and this abnormality is due to secondary hyperparathyroidism of CRF since resting levels of cytosolic calcium of the islets are normal in CRFPTX rats. Further support for an effect of excess PTH on cytosolic calcium is provided by two other observations. First, Fadda et al. (2) have shown that the acute exposure of the islets to PTH is followed by a significant rise in their cytosolic calcium. Second, Perna et al. (3) have demonstrated marked elevation in resting levels of cytosolic calcium in pancreatic islets after chronic administration of PTH to rats with normal renal function. Thus, it is apparent that chronic excess of PTH in the presence or absence of CRF causes a marked rise in resting levels of cytosolic calcium of pancreatic islets and is associated with impaired insulin secretion by these structures.

Table IV. Content of Glucose-6-Phosphate and Glycerol Phosphate in Myocardium and Skeletal Muscle of Control, $C R F$, and CRF-PTX Rats

\begin{tabular}{cclll}
\hline \multicolumn{2}{c}{ Myocardium } & & \multicolumn{2}{c}{ Skeletal muscle } \\
${$\cline { 2 - 3 }$}$ Gly-P $}$ & G-6-P & Gly-P \\
\hline nmol/mg protein
\end{tabular}

$\begin{array}{ccccc}\begin{array}{c}\text { Control } \\ n=6\end{array} & 1.83 \pm 0.15 & 4.55 \pm 0.49 & 3.21 \pm 0.22 & 2.11 \pm 0.20 \\ \text { CRF } & & & & \\ \quad n=6 & 1.32 \pm 0.09^{*} & 2.58 \pm 0.22^{*} & 1.54 \pm 0.35^{*} & 1.27 \pm 0.24^{*} \\ \begin{array}{c}\text { CRF-PTX } \\ n=6\end{array} & 1.66 \pm 0.11 & 3.81 \pm 0.22 & 2.74 \pm 0.33 & 2.49 \pm 0.37\end{array}$

G-6-P, glucose-6-phosphate; Gly-P, glycerol phosphate.

$* P<0.01$ from control and CRF-PTX.
Parathyroid hormone is known to augment calcium entry into many cells (25-29). However, cells are endowed with mechanisms that allow them to pump out the excess calcium and/or buffer it by intracellular organelles (30). The demonstration in our study that the resting levels of cytosolic calcium in islets of CRF rats are elevated indicates that the balance between calcium entry into, its extrusion out of, or its buffering within the cells is impaired. Calcium extrusion out of cells is accomplished, in major part, by the intact function of calciumactivated ATPase (30-32). ATP is needed for the functional integrity of this enzyme $(33,34)$. Our observation that the basal ATP content of islets isolated from CRF rats is significantly reduced may, at least in part, cause a reduction in the activity of the calcium-activated ATPase. Indeed, our studies show that the $V_{\max }$ of $\mathrm{Ca}^{2+}$ ATPase of pancreatic islets is significantly reduced compared with that of islets from control or CRF-PTX rats. Such a derangement would result in a rise in the resting levels of cytosolic calcium of the islets of these animals. The data of Corkey et al. (35) provide support for an effect of ATP on cytosolic calcium of islets since they demonstrated that the steady-state free calcium concentration in permeabilized

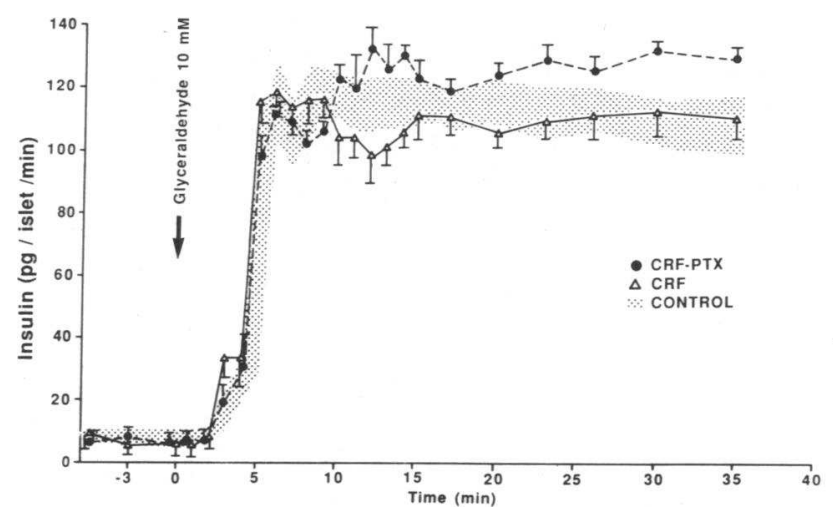

Figure 2. Dynamic studies of D-glyceraldehyde-induced insulin release from perifused pancreatic islets in four control, four CRF, and four CRF-PTX rats. Insulin secretion was first measured during dynamic perifusion with KRB containing $2.8 \mathrm{mM}$ D-glucose. At 0 time, the perifusate was changed to KRB containing $2.8 \mathrm{mM}$ Dglucose and $10 \mathrm{mM}$ D-glyceraldehyde. The shaded area represents mean $\pm 1 \mathrm{SE}$. Each data point represents the mean value and brackets denote $\pm 1 \mathrm{SE}$. There was no significant difference between the insulin secretion in the three groups of animals. 


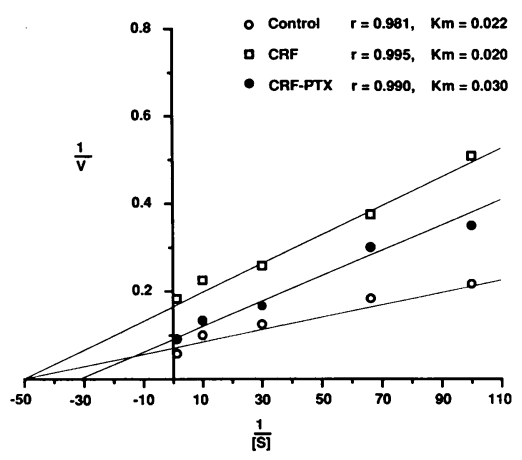

Figure 3. A representative study of $K_{\mathrm{m}}$ for calcium of $\mathrm{Ca}^{2+}$ ATPase of pancreatic islet membranes from control rats (O), CRF rats (口), CRF-PTX rats (๑). The data are presented as the Lineweaver-Burk plot demonstrating its linearity. The plot represents the reciprocal of the initial velocity

$(V)$ vs. the reciprocal of the initial substrate $[S]$ concentrations which yields a line whose slope is $K_{\mathrm{m}} / V_{\max }$, whose $y$ intercept is $1 / V_{\max }$, and whose $x$ intercept is $-1 / K_{\mathrm{m}}$.

RINm5F insulinoma cells varied inversely with ATP/ADP ratio.

Previous studies from our laboratory have demonstrated that a PTH-induced increase in the calcium burden of skeletal muscle (36) and heart (37) was associated with impaired mitochondrial oxygen consumption and reduced ATP content of these organs. Furthermore, a rise in the resting levels of cytosolic calcium in pancreatic islets of PTH-treated rats was associated with a fall in the basal levels of ATP (3). These observations taken together with the results of this study are consistent with the notion that the PTH-augmented entry of calcium into the islets of CRF rats is responsible for the reduction in their ATP content. Support for this explanation is provided by our finding of a normal ATP content in islets of CRF-PTX rats in which the resting levels of cytosolic calcium are normal despite CRF. It appears, therefore, that a vicious circle develops in islets of CRF rats where a rise in cytosolic calcium induced by PTH reduces ATP content, which in turn perpetuates the increase in cytosolic calcium. This situation continues until a new steady state develops with high levels of resting cytosolic calcium and low levels of ATP.

Since the two major metabolic disturbances in the islets of CRF rats are a rise in resting levels of cytosolic calcium and a reduction in basal ATP content, one must consider these events as potentially responsible for the impaired insulin secretion in CRF. Available data assign an important role for ATP in the process of insulin secretion by the pancreatic islets. ATP facilitates the closure of ATP-dependent potassium channels $(38,39)$, which is followed by cell depolarization $(39,40)$ and subsequent activation of voltage-sensitive calcium channels $(39,41)$. As a consequence, calcium enters the islets causing a rise in cytosolic calcium concentration that triggers cellular events that lead to insulin secretion. Corkey et al. (35) postulated that it is the ATP/ADP ratio that is important in the sequence of events described above, and a rise in the ATP/ADP ratio initiates the closure of the ATP-sensitive potassium channels and the depolarization of islets. Thus, the lower ATP content and/or the lower ATP/ADP ratio in islets of CRF rats both in the resting state and after exposure to $16.7 \mathrm{mM}$ D-glucose may contribute to the impaired insulin secretion through an effect on the ATP-dependent potassium channels $(38,39)$.

Calcium serves as a second messenger in many biological function of the cell (42). In order for calcium to act as such, the ratio between the calcium signal (rise in cytosolic calcium) induced by an agonist and the background calcium resting (cyto- solic calcium) should be of certain magnitude and adequately large (43). Therefore, in any situation where the resting levels of cytosolic calcium are elevated, the signal:background ratio will be smaller than in conditions with normal resting cytosolic calcium, and therefore the biological response to the calcium signal will be reduced. Thus, it is reasonable to suggest that the elevated levels of resting cytosolic calcium in islets of CRF rats would be associated with reduced glucose-induced insulin release.

The elevation in the resting levels of cytosolic calcium and the reduction in basal ATP content of islets of CRF rats may affect glucose-induced insulin release through other metabolic pathways as well. For glucose-induced insulin release to occur glucose must enter the islets and be appropriately metabolized by them. Also the islets must contain adequate amount of insulin.

It is apparent from our study that glucose uptake by the islets of CRF rats was not altered. The significant reduction in insulin content of these islets may have contributed to the impaired insulin release. However, one must be cautious in accepting this interpretation since the content of insulin in islets of CRF rats was 30 times higher than the amount secreted during the $30 \mathrm{~min}$ of the study. Further, D-glyceraldehyde caused a normal secretion of insulin from the islets of CRF rats despite their lower insulin content.

Several observations in our study indicate that glucose metabolism is impaired in the islets of CRF rats. After the entry of glucose into the islets, it is phosphorylated to glucose-6-phosphate, converted by an isomerase to fructose-6-phosphate, and further phosphorylated by PFK-1 to fructose 1,6 biphosphate (44). These processes require adequate amounts of ATP and intact function of the PFK-1. Our findings of low basal ATP content and noncompetitive inhibition of PFK-1 (normal $K_{\mathrm{m}}$ and reduced $V_{\max }$ ) indicate that glucose metabolism is impaired at a step(s) of the glycolytic pathway before the production of glyceraldehyde-3 phosphate. Further support for impaired glycolysis in islets from CRF rats is provided by our observations that net lactic acid production is markedly lower in these islets than in those from control or CRF-PTX rats. A definite evidence for impaired glucose metabolism by pancreatic islets of CRF rats could be provided by measurements of glucose intermediates. Unfortunately, we could not reliably measure the picomole quantities of these intermediates in the islets because of the small amount of tissue available for the assay. However, we measured these compounds in the myocardium and skeletal muscle of control, CRF, and CRF-PTX rats and found that glucose-6-phosphate and glycerol phosphate are significantly lower in CRF rats than in the other two groups of animals. This finding supports the proposition that CRF with excess PTH could impair glucose phosphorylation and metabolism in cells.

Our results demonstrating that glyceraldehyde-induced insulin release by islets from CRF rats is not different from that of islets from normal rats are also consistent with the interpretation that CRF with excess PTH impairs glucose metabolism in islets, since glyceraldehyde enters the glycolytic pathway at the triose phosphate isomerase level (44).

Several lines of evidence indicate that CAMP modulates insulin secretion in response to nutrients $(41,45,46)$. The reduction in glucose-induced insulin release by the islets of CRF rats does not seem to be related to derangements in adenylate cyclase-cAMP systems. Indeed, cAMP contents of islets of 
CRF rats after their exposure to glucose or IBMX were not different from those observed in normal islets despite reduced insulin release by the CRF islets.

Finally, it should be mentioned that the pancreatic islet is not a homogeneous structure and contains other cell types besides the $\beta$ cells; the latter, however, constitute $70-80 \%$ of all cells of the islet. Therefore, the changes in the cytosolic calcium, ATP content, net lactic acid output, and $V_{\max }$ of $\mathrm{Ca}^{2+}$ ATPase of the islets of CRF rats may modestly overestimate or underestimate the magnitude of these changes in the $\beta$ cells depending on the effect of CRF on these parameters in the other cell type of the islet.

\section{Acknowledgments}

We wish to thank Mr. Varoujan Galfayan for his excellent technical assistance, and Mrs. Mary L. Benson and Mrs. Rhonda Woods for their valuable secretarial assistance. We are indebted to Dr. Linda Cheng and Dr. Charles R. Filburn for the measurement of PTH.

This work was supported by grant DK 29955 from the National Institute of Diabetes, Digestive and Kidney Diseases. Dr. Perna is a fellow of the National Kidney Foundation of Southern California.

\section{References}

1. Fadda, G. Z., M. Akmal, F. H. Premdas, L. G. Lipson, and S. G. Massry. 1988. Insulin release from pancreatic islets: effects of CRF and excess PTH. Kidney Int. 33:1066-1072.

2. Fadda, G. Z., M. Akmal, L. G. Lipson, and S. G. Massry. 1990. Direct effect of parathyroid hormone on insulin secretion from pancreatic islets. Am. J. Physiol. 258:E975-E984.

3. Perna, A. F., G. Z. Fadda, X.-J. Zhou, and S. G. Massry. 1990. Mechanisms of impaired insulin secretion following chronic excess of parathyroid hormone. Am. J. Physiol. 259:F210-F216.

4. Fadda, G. Z., M. Akmal, A. R. Soliman, L. G. Lipson, and S. G. Massry. 1989. Correction of glucose intolerance and the impaired insulin release of chronic renal failure by verapamil. Kidney Int. 36:773-779.

5. Lacy, P. E., and M. Kostianovsky. 1967. Methods for isolation of intact islets of Langerhans from the rat pancreas. Diabetes. 16:35-39.

6. Molina, J. M., F. Premdas, and L. G. Lipson. 1985. Insulin release in aging: dynamic response of isolated islets of Langerhans of the rat to D-glucose and D-glyceraldehyde. Endocrinology. 116:821-826.

7. Molina, J. M., F. Premdas, R. E. Klenck, G. Eddelstone, S. B. Oldham, and L. G. Lipson. 1984. The insulin secretory response of isolated pancreatic islets of the diabetic mouse. Diabetes. 33:1120-1123.

8. Ashcroft, S. J. H., L. C. C. Weerasinghe, and P. J. Randle. 1972. Inter-relationship of islet metabolism, adenosine triphosphate content and insulin release. Biochem. J. 132:223-231.

9. Lundin, A., M. Hasenson, J. Persson, and A. Pousette. 1986. Estimation of biomass in growing cell line by adenosine triphosphate assay. Methods Enzymol. 133:27-43.

10. Beutler, E. 1975. Red cell metabolism. Manual of Biochemical Methods. Grune \& Stratton, Inc., NY. 42-44.

11. Hyslop, P. A., D. B. Hinshaw, W. A. Hasley, Jr., I. V. Schraufstatter, R. C Spragg, J. H. Jackson, and C. G. Cochrane. 1988. Mechanisms of oxidant-mediated cell injury. The glycolytic and mitochondrial pathways of ADP phosphorylation are major intracellular targets inactivated by hydrogen peroxide. J. Biol. Chem. 263:1665-1675.

12. Bradford, M. 1976. A rapid sensitive method for the quantitation of microgram quantities of protein utilizing the principle of protein-dye binding. Anal. Biochem. 72:248-254.

13. Bessman, S. P., P. J. Geiger, T. Sung-Cho-Lu, and E. R. B. McCahe. 1974. Separation and automated analysis of phosphorylated metabolic intermediates. Anal. Biochem. 59:533-546.

14. Brautbar, N., J. Tabernero-Romo, J. C. Coats, and S. G. Massry. 1984. Impaired myocardial lipid metabolism in phosphate depletion. Kidney Int. 26:18-23.

15. Sener, A., and W. J. Malaisse. 1976. Reliability of such a method as an index of glycolysis in pancreatic islets. Biochem. Med. 15:34-41.

16. Sussman, K. E., J. W. Leitner, and B. Draznin. 1987. Cytosolic free calcium concentrations in normal pancreatic islets cells. Diabetes. 36:571-577.
17. Grynkiewicz, G., M. Poenie, and R. Y. Tsien. 1985. A new generation of $\mathrm{Ca}^{2+}$ indicators with greatly improved fluorescence properties. J. Biol. Chem. 260:3440-3450.

18. Tsien, R. Y., T. Pozzan, and T. J. Rink. 1982. T cell mitogen caused early changes in cytoplasmic $\mathrm{Ca}^{2+}$ and membrane potential in lymphocytes. Nature (Lond.). 295:68-71.

19. Draznin, B., K. E. Sussman, R. H. Eckel, M. Kao, T. Yost, and N. A. Sherman. 1988. Possible role of cytosolic free calcium concentrations in mediating insulin resistance of obesity and hyperinsulinemia. J. Clin. Invest. 82:18481852.

20. Levin, S. R., B. G. Kasson, and J. F. Driessen. 1978. Adenosine triphosphatases of rat pancreatic islets comparison with those of rat kidney. J. Clin. Invest. 62:692-701.

21. Lundin, A., A. Richardson, and A. Thore. 1976. Continuous monitoring of ATP-converting reactions by purified firefly luciferase. Anal. Biochem. 75:611-620.

22. Pershadsingh, H. A., M. L. McDaniel, M. Landt, C. G. Bry, P. E. Lacy, and J. M. McDonald. 1980. $\mathrm{Ca}^{2+}$-activated ATPase and ATP-dependent calmodulin-stimulated $\mathrm{Ca}^{2+}$ transport in islet cell plasma membrane. Nature (Lond.). 288:492-495.

23. Herbert, V., K. S. Lau, C. W. Gottlieb, and S. J. Bleicher. 1965. Coated charcoal immunoassay for insulin. J. Clin. Endocrinol. \& Metab. 25:1375-1384.

24. Akmal, M., S. G. Massry, D. A. Goldstein, P. Fanti, A. Weisz, and R. A. Defronzo. 1985. Role of parathyroid hormone in the glucose intolerance of chronic renal failure. J. Clin. Invest. 75:1037-1044.

25. Chausmer, A. B., B. S. Sherman, and S. Wallach. 1972. The effect of parathyroid hormone on hepatic cell transport of calcium. Endocrinology. 90:663-672.

26. Borle, A. B. 1973. Calcium metabolism at the cellular level. Fed. Proc. 30:1944-1950.

27. Bogin, E., S. G. Massry, and I. Harary. 1981. Effect of parathyroid hormone on rat heart cells. J. Clin. Invest. 67:1215-1227.

28. Bogin, E., S. G. Massry, J. Levi, M. Djaldeti, G. Bristol, and J. Smith 1983. Effect of parathyroid hormone on osmotic fragility of human erythrocyte. J. Clin. Invest. 69:1017-1025.

29. Fraser, C. L., P. Sarnacki, and A. Budayr. 1988. Evidence that parathyroid hormone-mediated calcium transport in rat brain synaptosomes is independen of cyclic adenosine monophosphate. J. Clin. Invest. 81:982-988.

30. Carafoli, E. 1987. Intracellular calcium homeostasis. Annu. Rev. Biochem. 56:395-433.

31. Schatzman, J. H., and F. F. Vincenzi. 1969. Calcium movement across the membrane of human red cell. J. Physiol. (Lond.). 201:236-355.

32. Blaustein, M. P., and A. C. Hodgkin. 1969. The effect of cyanide on the efflux of calcium from squid axon. J. Physiol. (Lond.). 200:497-527.

33. Blaustein, M. P. 1974. The interrelationship between sodium and calcium fluxes across cell membranes. Rev. Physiol. Biochem. Pharmacol. 70:33-82.

34. Baker, P. F., and P. A. McNaughton. 1976. Kinetics and energetics of calcium efflux from intact squid giant axon. J. Physiol. (Lond.). 259:103-144.

35. Corkey, B. E., J. T. Deeney, M. C. Glennon, F. M. Matschinsky, and M. Prentki. 1988. Regulation of steady-state free $\mathrm{Ca}^{2+}$ levels by ATP/ADP ratio and orthophosphate in permeabilized RINm5F insulinoma cells. J. Biol. Chem. 263:4247-4253.

36. Baczynski, R., S. G. Massry, M. Magott, S. El-Belbessi, R. Kohan, and N. Brautbar. 1985. Effect of parathyroid hormone on energy metabolism of skeletal muscle. Kidney Int. 28:722-727.

37. Baczynski, R., S. G. Massry, R. Kohan, M. Magott, Y. Saglikes, and N. Brautbar. 1984. Effects of parathyroid hormone on myocardial energy metabolism in the rat. Kidney Int. 27:718-725.

38. Cook, D. L., and C. N. Hales. 1984. Intracellular ATP directly blocks $\mathrm{K}^{+}$ channels in pancreatic $\beta$-cells. Nature (Lond.). 311:271-273.

39. Prentki, M., and F. M. Matchinsky. 1987. $\mathrm{Ca}^{2+}$, cAMP and phospholipidderived messengers in coupling mechanisms of insulin secretion. Physiol Rev. 67:1185-1248.

40. Henquin, J. C., and H. P. Meissner. 1984. Significance of ionic fluxes and changes in membrane potential for stimulus secretion coupling in pancreatic $\beta$ cells. Experientia (Basel). 40:1043-1052.

41. Hedeskov, C. J. 1980. Mechanisms of glucose-induced insulin secretion. Physiol. Rev. 60:442-509.

42. Rasmussen, H., and P. Q. Barrett. 1984. Calcium messenger system: an integrated view. Physiol. Rev. 64:938-984.

43. Blaustein, M. P. 1988. Calcium transport and buffering in neurones. Trends Neurosci. 11:438-443.

44. Stadtman, E. R. 1966. Allosteric regulation of enzyme activity. Adv. Enzymol. Relat. Areas Mol. Biol. 28:141-154.

45. Malaisse, W. J., J. C. Hotton, A. R. Carpinelli, A. Herchuel, I. Valverde, and A. Sensor. 1980. The stimulus-secretion coupling of amino acid-induced insulin release. Metabolism and cationic effects of leucine. Diabetes. 29:431-437.

46. Malaisse, W. J., and F. Malaisse-Lagae. 1984. The role of cyclic AMP in insulin release. Experientia (Basel). 40:1068-1075. 